\title{
Species occurrence of cetaceans in Guinea, including humpback whales with southern hemisphere seasonality
}

\author{
I.L. BAMY ${ }^{1}$, K. VAN WAEREBEEK ${ }^{2}$, S.S. BAH ${ }^{3}$, M. DIA ${ }^{4}$, B. KABA ${ }^{5}$, N. KEITA ${ }^{3}$ AND S. KONATE \\ ${ }^{1}$ Centre National des Sciences Halieutiques de Boussoura (CNSHB), BP-3738 Boussoura, Conakry, Guinea, ${ }^{2}$ COREWAM-Ghana, \\ PO Box PG99, EcoLab, University of Ghana, \& CEPEC, Museo de Delfines, Pucusana, Lima 20, Peru, ${ }^{3}$ Direction Nationale de la \\ Protection de la Nature, Ministère de l'Environnement, Conakry, Guinea, ${ }^{4}$ Direction Nationale des Eaux et Forêts, Ministère de \\ l'Agriculture, de l'Elevage et des Forêts, Conakry, Guinea, ${ }^{5}$ Centre de Recherches Océanographiques de Rogbané (CERESCOR), \\ BP 561 Rogbané, Conakry, Guinea
}

\begin{abstract}
An initial inventory of the dolphins and whales occurring in Guinea's coastal waters is documented primarily from specimens and photographic evidence obtained from strandings and by-catches. Seven species are fully validated, four odontocetes, Tursiops truncatus, Sousa teuszii, Stenella frontalis, Kogia breviceps and three balaenopterid whales: Balaenoptera brydei, Balaenoptera acutorostrata and Megaptera novaeangliae. Another three reported species (Globicephala macrorhynchus, Steno bredanensis and Delphinus delphis) are insufficiently supported but thought to be valid. Small cetaceans landed as by-catch and a stranded whale were used for human consumption, but no evidence of substantial takes, directed or by-catch, was found. However, concern is raised about even minimal takes of the vulnerable Atlantic humpback dolphin. The seasonal presence of three confirmed humpback whales, two strandings (July and September) and a sighting (October), is synchronous with the species' southern hemisphere wintering/breeding season in low latitudes. We hypothesize that these whales may comprise the north-westernmost range of the population that breeds/overwinters in coastal waters of the Bight of Benin, northern Gulf of Guinea.
\end{abstract}

Keywords: Guinea, eastern tropical Atlantic, whales, dolphins, occurrence, by-catch, strandings, biodiversity

Submitted 31 July 2009; accepted 17 March 2010

\section{INTRロDUCTIDN}

There is a paucity of published information on the occurrence of dolphins and whales off the Atlantic coast of Guinea in West Africa, and no dedicated literature exists. In an extensive review of fisheries-cetacean interactions from the West African coast by Maigret (1994), no evidence was reported from its $300 \mathrm{~km}$ coastline stretching from Guinea-Bissau in the north (coastal border at $10^{\circ} 55^{\prime} \mathrm{N} 15^{\circ} 03^{\prime} \mathrm{W}$ ) to Sierra Leone in the south (coastal border at $09^{\circ} 02^{\prime} \mathrm{N} 15^{\circ} 18^{\prime} \mathrm{W}$ ) (Figure 1). The Soviet vessel RV 'Evrika' surveyed the Guinean coast in May-July 1984 and mapped five sightings of unidentified coastal dolphins within the $200 \mathrm{~m}$ isobath (two within the $20 \mathrm{~m}$ isobath) plus an unidentified whale between the 200 and $500 \mathrm{~m}$ isobaths (Anonymus, 1984). A few cetacean sightings in Tormosov et al. (1980), although possibly relevant for Guinean waters, lack coordinates and, plotted as large symbols on a small-scale map of Africa, do not allow reliable interpretation. Jefferson et al. (1997) cited and considered Guinea as a possible range state for five small cetaceans based on the literature, as reviewed below.

In May 2000, the Guinean Ministry of Agriculture, jointly with the Convention on the Conservation of Migratory

Corresponding author:

K. Van Waerebeek

Email: corewam@gmail.com
Species of Wild Animals (CMS), organized a regional workshop in Conakry on the conservation and management of small cetaceans from West Africa, in which several of the authors participated. The meeting called for, inter alia, the inventory of cetacean species, the collection, treatment and compilation of data for each range state, and improved surveillance and regulation of fisheries with respect to by-catches (Archer \& Van Waerebeek, 2000; CMS, 2000). Circa 2001, Guinea's Centre National des Sciences Halieutiques de Boussoura (CNSHB) embarked on a pioneering effort to collect basic field data, evaluate evidence from various sources and produce a first inventory of cetacean biodiversity, the results of which we present below.

\section{MATERIALS AND METHDDS}

Cetacean records documented here result mainly from observations achieved during irregular, often opportunistic, surveys of fishers' communities by CNSHB personnel in 2001-2003, typically in follow-up on verbal accounts received from local agents stationed in key fish landing sites. Most study material originated from stranding and by-catch events as documented by voucher specimens, photographs, video and descriptions of diagnostic features. An exhaustive literature search yielded a minimal amount of additional substantiated information. References were traced back to their original sources and 


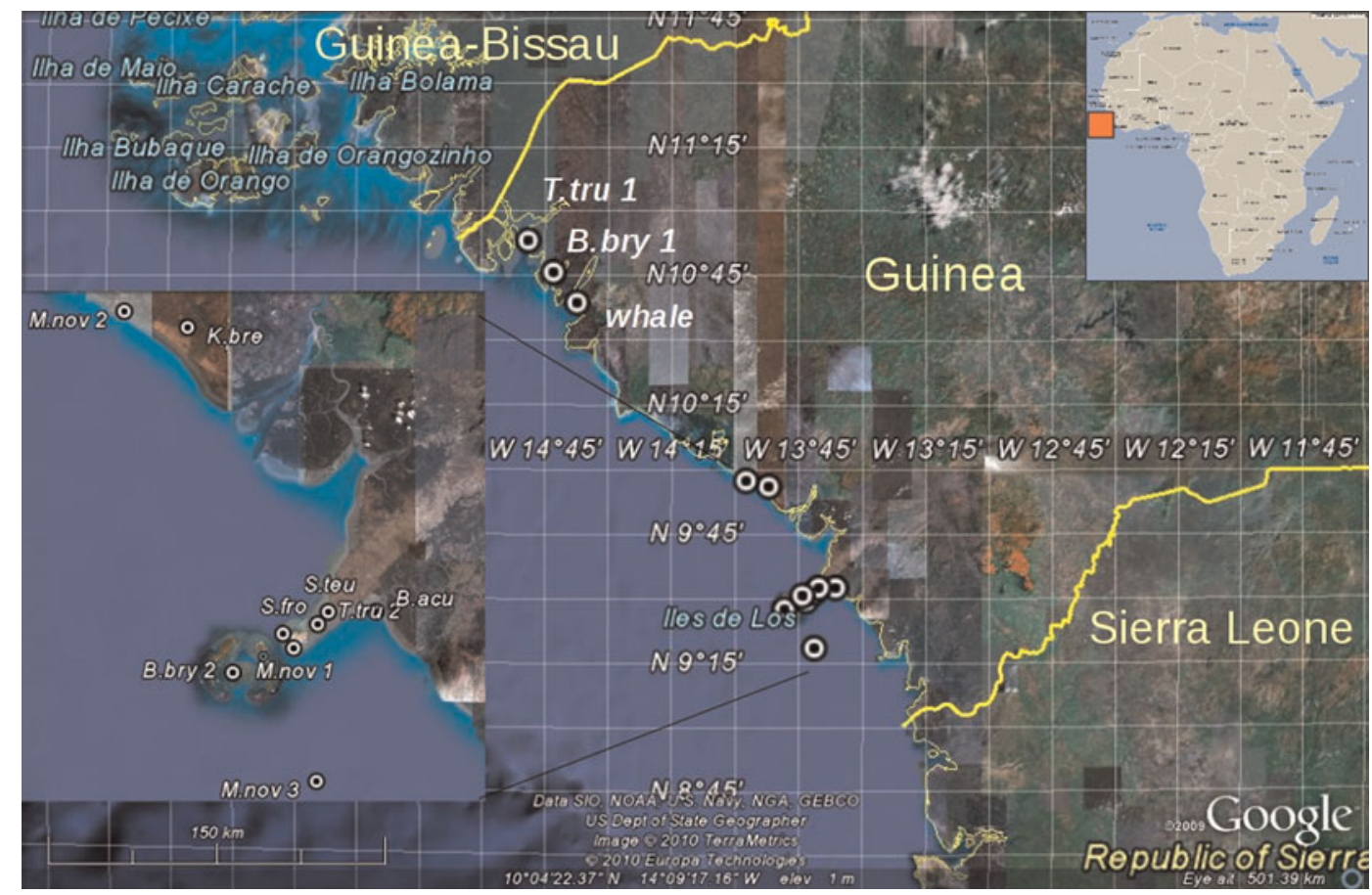

Fig. 1. The coastal area of Guinea with locations for ten fully documented cetacean records (landings, strandings, one sighting) and one unidentified baleen whale (see text). Abbreviations used: Megaptera novaeangliae (M.nov), Balaenoptera brydei (B.bry), Balaenoptera acutorostrata (B.acu), Tursiops truncatus (T.tru), Sousa teuszii (S.teu), Kogia breviceps (K.bre) (satellite images (C)2009 Google, (C)2010 TerraMetrics, (C)2010 Europa Technologies).

any claims based on distributional inference rather than observational data were not further considered. A cetacean morphologist (K.V.W.) critically examined all available evidence. Distances between locations were computed with GPS Mapsource 6.4 software (C) 2004 Garmin Corporation). 'West Africa' is used sensu the UN definition, i.e. the westernmost region of Africa, from Mauritania south and east to Nigeria. Records are plotted (Figure 1) on a satellite hybrid map of the study region (C) 2009 Google).

\section{Study area}

Guinea has a tropical climate with alternating dry and rainy seasons. Thanks to physical factors including shallow waters, a strong tidal regime and pronounced seasonal pluviosity, large parts of the coastal zone are covered in extensive mangrove forests. The continental shelf of almost $43,000 \mathrm{~km}^{2}$ represents the greatest submerged surface off the West African coast. Its width varies from 87 nautical miles $(161 \mathrm{~km})$ in the south to 104 nautical miles $(193 \mathrm{~km})$ in the north (Rougeron, 1996). Guinea's seabed consists of muds and sandy muds, containing terrigenous particles deposited by several rivers (Postel, 1955; Domain \& Bah, 1993). Beyond the $20 \mathrm{~m}$ isobath, sandy bottoms predominate. On the edge of the old submarine valleys, especially in the north, the sea bottom is characterized by the presence of exposed rock formations (ridins) up to $5 \mathrm{~m}$ high, hazardous to bottom trawling. In the rainy season (April-November) south-westerly winds predominate. Always north of the equator, the warm, south-eastward-flowing Guinea Current changes position with the seasons so that its northern limit lies at approximately $7^{\circ} \mathrm{N}$ during the winter and $15^{\circ} \mathrm{N}$ during the summer. Sea surface temperatures, averaging $28-29^{\circ} \mathrm{C}$, show little seasonal variation. Surface salinity exceeds $32.0 \%$ on the coast and steeply increases to $35.5 \%$ further offshore.

\section{RESULTS}

\section{Family Delphinidae Gray, 1821}

\section{ATLANTIC HUMPBACK DOLPHIN SOUSA TEUSZII}

(KÜKENTHAL, 1892)

Although thought to be widely distributed in Guinea (Cadenat, 1956a, 1959) the only documented S. teuszii specimen is a $222-\mathrm{cm}$ male (Figure 2) landed by artisanal fishers at Dixinn ( $09^{\circ} 33^{\prime} \mathrm{N} 13^{\circ} 40^{\prime} \mathrm{W}$; 'S.teu' in Figure 1), baie de

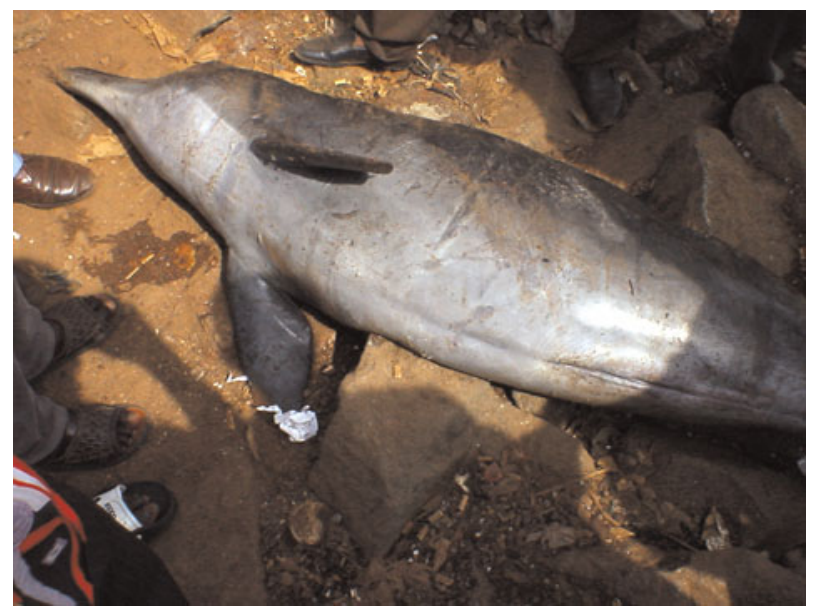

Fig. 2. A male Atlantic humpback dolphin, Sousa teuszii, for sale at the fish landing site of Dixinn, Baie de Sangaréah, on 13 March 2002. 
Sangaréah, on 13 March 2002 (Van Waerebeek et al., 2004). The animal's sexual organs, stored in formalin, are deposited at CNSHB. No other recent sightings have been reported but marine biologist Jean Cadenat (1956a, p. 558) stated [literal translation from French] 'the characteristic shape of the dorsal fin of this species and its colour pattern [...] make me think today that the delphinids which showed exactly these characteristics and which I could observe in January 1953 in the silt-laden inshore waters of French Guinea, south of Conakry, must also belong to the species Sotalia teuszii. This account, although not authenticated, is credible considering Cadenat had ample first-hand expertise with the species. Van Waerebeek et al. (2004) provisionally defined a 'South Guinea' management stock. Two of us (I.L.B. and K.V.W.) interviewed fishermen in the Baie de Sangaréah area in April 2006 who described dolphins matching the diagnostic features of humpback dolphins as occasionally entangled in their nets. It is unclear whether the Cadenat (1959) claim of the species being 'very common' off Guinea is still valid today.

\section{COMMON BOTTLENOSE DOLPHIN TURSIOPS}

TRUNCATUS (MONTAGU, 1821)

A $340 \mathrm{~cm}$ adult female was landed in fresh condition at Bonfi, Salatougou, $200 \mathrm{~km}$ north-west of Conakry $\left(13^{\circ} 18^{\prime} \mathrm{N}\right.$ $09^{\circ} 03^{\prime} 30^{\prime \prime} \mathrm{W}$; 'T.tru1' in Figure 1) on 10 March 2002. The dolphin, a by-catch victim, showed net marks on the dorsum and anterior flanks. This specimen is the first documented T. truncatus record for Guinea and represents a new country record (Figure 3). The skull and a full set of standard cranial measurements are deposited at CNSHB. Considering slightly eroded occipital condyli in the Bonfi specimen, its minimum condylobasal length (CBL) of $556 \mathrm{~mm}$ is consistent with adult CBL ranges of 540-610 mm (Robineau \& Vely, 1997) and 504-578 mm (Ross, 1984) for Senegal and

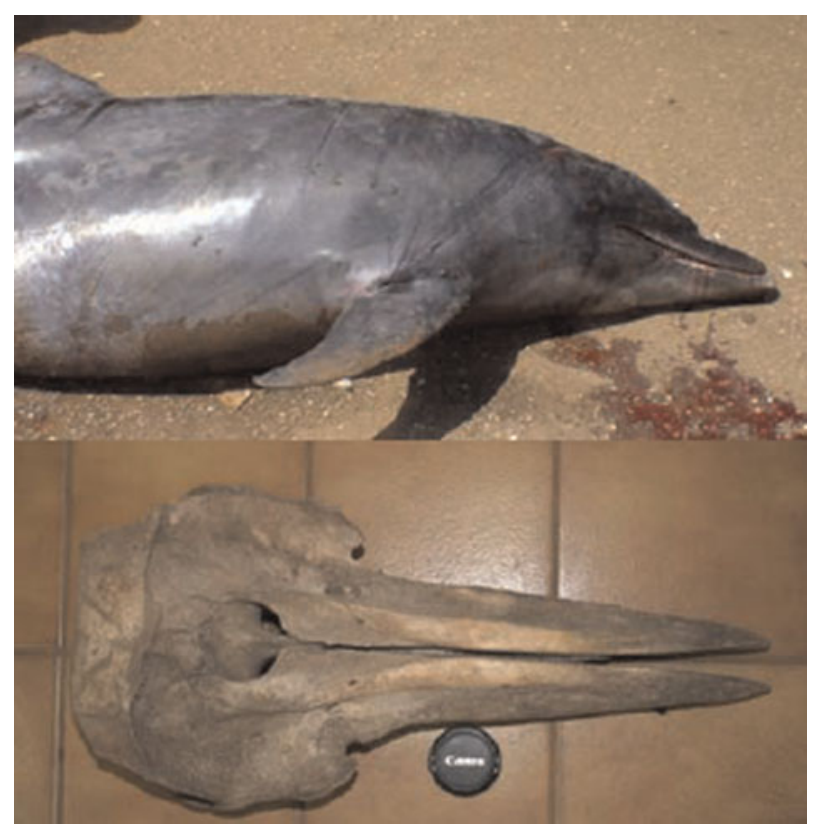

Fig. 3. A common bottlenose dolphin, Tursiops truncatus, landed at Bonfi on 10 March 2002 and its skull, deposited at the CNSHB reference collection. Diameter of scale (lens cap) is $60 \mathrm{~mm}$. southern Africa respectively. The high values found for CBL and rostrum length $(335 \mathrm{~mm})$ are in accordance with the elongate rostra noticeable even in some free-ranging T. truncatus from West Africa (e.g. Van Waerebeek et al., 2008).

A second T. truncatus by-catch was landed in fresh state at the port of Boulbinet $\left(09^{\circ} 30^{\prime} 11^{\prime \prime} \mathrm{N} 13^{\circ} 42^{\prime} 53^{\prime \prime} \mathrm{W}\right.$; 'T.tru2' in Figure 1), Conakry, on 11 December 2005, and was examined by a CNSHB team led by S.T. Diallo on 12 December 2005. It was briefly reported but without diagnostic evidence (Diallo et al., 2007). On 9 March 2010, from a photograph archived at CNSHB, K.V.W. could confirm the species as T. truncatus.

\section{ATLANTIC SPOTTED DOLPHIN STENELLA}

\section{FRONTALIS (G. CUVIER, 1829)}

M.E. Postel harpooned a $\sim 2$-m dolphin at an unspecified distance and position from Conakry (port at $09^{\circ} 30^{\prime} \mathrm{N} 13^{\circ} 43^{\prime} \mathrm{W}$; 'S.fro' in Figure 1) on 3 January 1953 and collected the head. It was assigned to the genus Prodelphinus Gervais 1880 (Cadenat, 1956b, 1959; Cadenat \& Lassarat, 1959) which is a junior synonym for Stenella Gray, 1866. Low tooth counts (32LL, 34LR, 32UL and 33UR), numerous large black spots on the lower jaw and below the eye, white spots on the otherwise dark dorsal side of the head and an upturned tip of the mandibles (see figure 27 in Cadenat 1956b; and figures 39 \& 40 in Cadenat, 1959) confirm the dolphin belongs to Stenella frontalis (G. Cuvier, 1829). Apparently the head was taken to Senegal and deposited at the Musée de la Mer, Institut Fondamental d'Afrique Noir (IFAN), Ile de Gorée (Cadenat, 1959). When studying and re-organizing the cetacean collection at that museum in 1999, one of us (K.V.W.) assigned a new catalogue number 'SN80' to a slightly damaged mummified dolphin head without associated reference (Van Waerebeek et al., 2000, p. 61). Visible cranial features revealed it belonged to Stenella, and probably $S$. frontalis, but X-ray examination would have been necessary for species confirmation. Van Waerebeek et al. (2000) assumed the dolphin head had been collected in Senegal. However, careful re-reading of Cadenat (1959) suggests that SN8o probably is the historical S. frontalis specimen from Conakry.

\section{Family Kogiidae Gill, 1871}

\section{PYGMY SPERM WHALE KOGIA BREVICEPS}

(DE BLAINVILLE, 1838)

An adult female of $340 \mathrm{~kg}$ landed by artisanal fishermen at the Dabondi landing site, just south of Conakry (commune Matoto), on 3 May 2002 and reportedly captured off Tanène $\left(09^{\circ} 56^{\prime} 29^{\prime \prime} \mathrm{N} 13^{\circ} 51^{\prime} 46^{\prime \prime} \mathrm{W}\right.$; 'K.bre' in Figure 1) represents the first record of $K$. breviceps in Guinea. The fresh carcass was butchered and locally consumed. The low dorsal fin set well behind body midpoint and its larger body size (Figure 4) positively distinguishes $K$. breviceps from the dwarf sperm whale Kogia sima (Owen, 1866). Body length of $345 \mathrm{~cm}$ as measured by one of us (I.B.) if not strictly axial may slightly overestimate standard length. The skull (CBL, $401 \mathrm{~mm}$ ) and partial skeleton is deposited in the CNSHB collection. Most epiphyses are fused to the vertebral centres indicating physical maturity, in agreement with its adult body length, however some epiphyseal fusion lines persist. 


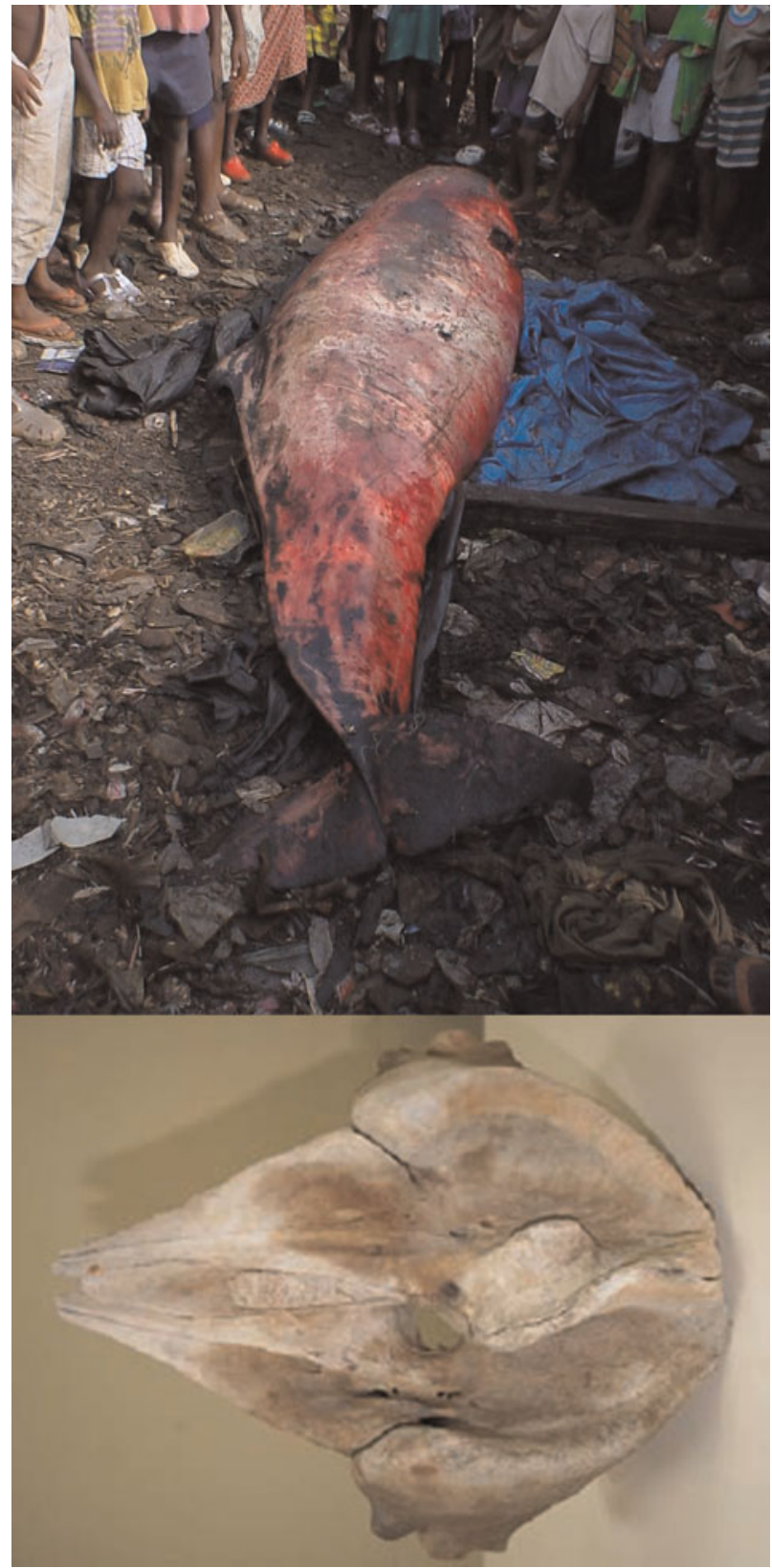

Fig. 4. Adult pygmy sperm whale, Kogia breviceps, landed as by-catch at Dabondy (photograph by Moussa Sylla) and (below) the skull curated at CNSHB. Note the low dorsal fin posteriad to the middle of the animal's dorsum.

\section{Family Balaenopteridae Gray, 1864}

\section{BRYDE'S WHALE BALAENOPTERA BRYDEI OLSEN,}

1913

Olsen's (1913) original description of B. brydei was based on whales taken off South Africa's Cape Province, however he did not assign a holotype. A meticulous morphological account by Lönnberg (1931) is generally considered as the primary reference for $B$. brydei description (see also Yamada et al., 2008). Soot-Ryen (1961) provided further morphological evidence to distinguish $B$. brydei from Eden's whale Balaenoptera edeni Anderson, 1879, a dwarf form endemic in the Indo-Pacific region. While for half a century most authors followed Junge (1950) who synonymized B. brydei

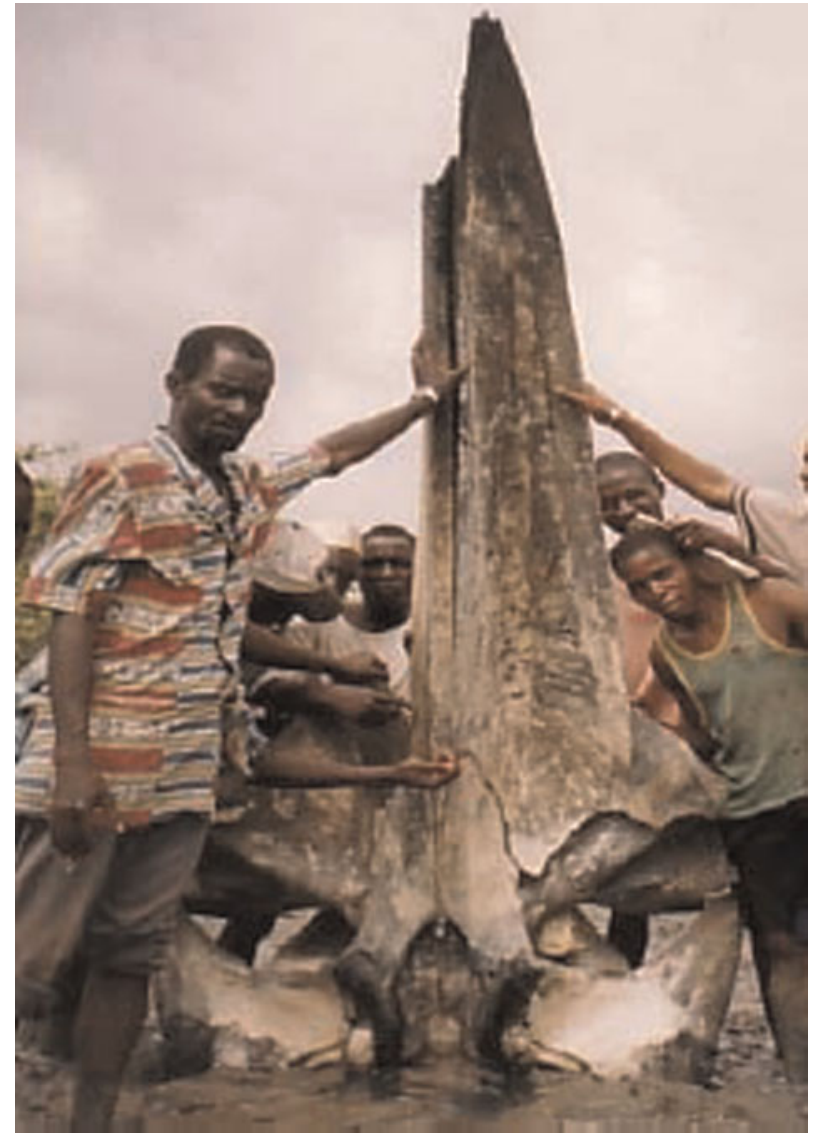

Fig. 5. Ventral view of the skull of a Bryde's whale, Balaenoptera brydei, stranded at Kanfarandé in May 2001.

with $B$. edeni, recently species-level differences are again recognized (e.g. Wada et al., 2003; Best, 2007; Kanda et al., 2007; Yamada et al., 2008).

A $13 \mathrm{~m} \mathrm{~B}$. brydei stranded in northern Guinea near Koukoubaya, Kanfarandé $\left(10^{\circ} 46.183^{\prime} \mathrm{N} 14^{\circ} 42.60^{\prime} \mathrm{W}\right.$; 'B.bry1' in Figure 1), Boké Préfecture, on 21 May 2001. The skull was examined by the senior author in July 2001. A photograph of the skull is the only remaining voucher available (Figure 5). Locals reported to have consumed the flesh of the whale, suggesting it stranded in fresh condition, if not alive.

A $9.8 \mathrm{~m} \mathrm{~B}$. brydei beached alive in daytime at Kassa (reportedly during a storm), Ile de Loos (09 $28^{\prime} \mathrm{N} 13^{\circ} 48^{\prime} \mathrm{W}$; 'B.bry2' in Figure 1) on 29 July 2002 (Figure 6). The stomachs contained unspecified teleost fish and squids. Two photographs of the stranded animal were examined, one showing

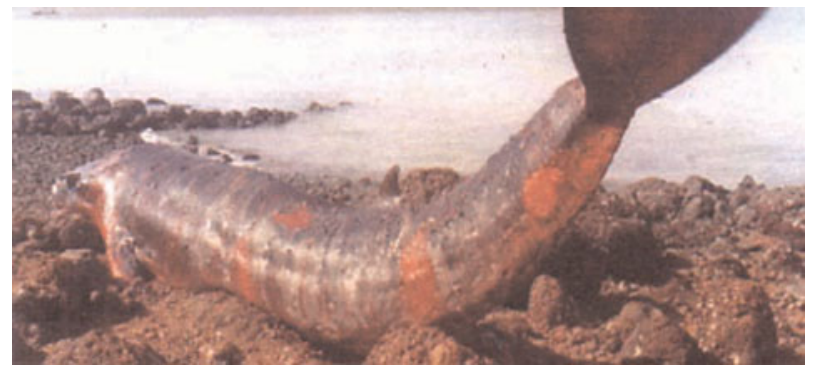

Fig. 6. Bryde's whale, Balaenoptera brydei, stranded alive at Kassa, Ile de Loos, in July 2002. 
the straight maxillar tip ${ }^{1}$ and a prominent falcate dorsal fin. The complete skeleton is mounted at the CNSHB headquarters in Conakry. Several osteological features combined characteristic for B. brydei are evident, i.e. maxillae with proximally nearly parallel borders, concave anterior margin of nasal bones and bent forward on the outer side, strongly curved and very robust mandibles and vertebrae with relatively short spinous processes which are heavily inclined backwards (Lönnberg, 1931; Omura et al., 1981; Cummings, 1985).

\section{COMMON MINKE WHALE BALAENOPTERA}

\section{ACUTOROSTRATA LACÉPÈDE, 1804}

A $B$. acutorostrata of unknown sex became entangled in a fishing net in the Bay of Tabounsou $\left(09^{\circ} 33^{\prime} \mathrm{N} 13^{\circ} 36^{\prime} \mathrm{W}\right.$; 'B.acu' in Figure 1) at the south end of Conakry and was landed at Gbessia-Port in March 1986 where it was inspected by one of us (B. Kaba). Two grainy photographs in a local newsletter article (Kaba \& Boltachev, 1986) support the event. However the colour pattern of the whale and its flippers was not recorded. The single baleen plate available, curated in the CERESCOR collection, measures $21 \mathrm{~cm}$ long for $6.5 \mathrm{~cm}$ wide, in agreement with the $23.5 \mathrm{~cm}$ maximum baleen plate length for North Atlantic B. acutorostrata (Jonsgård, 1951, his figures 2 and 3 ). The baleen plate (Figure 7 ) is cream-white with, labially, a grey-brown edge, has an almost straight outer edge and fine, short, cream-coloured bristles, all characteristic for minke whales (Jonsgård, 1951; Sergeant, 1963; Mitchell \& Kozicki, 1975). It is unclear whether the reported body length of $877 \mathrm{~cm}$ (Kaba \& Boltachev, 1986) was taken partly over the body curvature which is known to overestimate standard length. Horwood (1990, cited in Perrin \& Brownell, 2002) reports an average length for $B$. acutorostrata at physical maturity of $850-880 \mathrm{~cm}$ in females and $780-820 \mathrm{~cm}$ in males.

The Tabounsou specimen is the first $B$. acutorostrata record for Guinea, and one of very few authenticated records in West Africa (reviewed by Van Waerebeek et al., 1999). The former southernmost documented case in the north-east Atlantic was a juvenile, also a by-catch, landed at Hann $\left(14^{\circ} 41^{\prime} \mathrm{N} 17^{\circ} 27^{\prime} \mathrm{W}\right)$ on Senegal's central coast, more than $5^{\circ}$ latitude to the north (Van Waerebeek et al., 1999).

\section{HUMPBACK WHALE MEGAPTERA NOVAEANGLIAE}

(BOROWSKI, 1781)

The anterior half body of an adult-sized $M$. novaeangliae washed ashore at Téminitaye, Conakry $\left(09^{\circ} 30^{\prime} \mathrm{N} 13^{\circ} 42.9^{\prime} \mathrm{W}\right.$; 'M.nov1' in Figure 1) on 26 September 2005. The elongated flippers with prominent bumps on the leading edge and the low number of ventral pleats (14-17 estimated from photographs) confirmed the species (Figure 8). To judge from the advanced decomposition (code 4) death may have occurred sometime during the 2 nd or 3 rd week of September. The missing posterior body strongly suggests a collision with a large vessel, either ante-mortem or post-mortem. A second adult $M$. novaeangliae stranded at Taboriya, Boffa $\left(09^{\circ} 57^{\prime} 50^{\prime \prime} \mathrm{N} 13^{\circ} 57^{\prime} 0^{\prime \prime} \mathrm{W}\right.$; 'M.nov2' in Figure 1) on 22 July 2008 (Figure 9). No samples were taken from either whale. A third record, a live animal, was sighted on the shelf some $24.5 \mathrm{~km}$ from shore, at $09^{\circ} 19^{\prime} \mathrm{N} 13^{\circ} 41^{\prime} \mathrm{W}$ ('M.nov3' in Figure 1) on 1 October 2002 during a dedicated oceanographic

${ }^{1}$ Distinct from downward tilted rostrum tip in sei whale Balaenoptera borealis Lesson, 1828 .

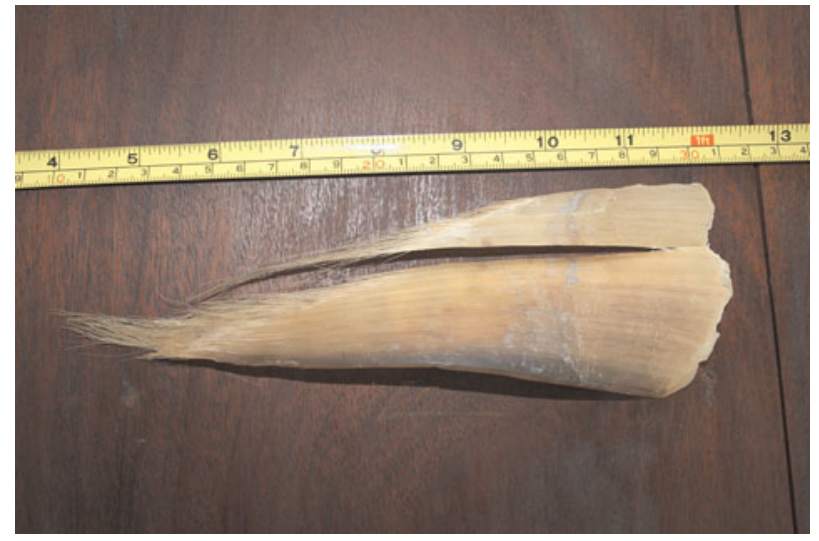

Fig. 7. Baleen plate of a common minke whale, Balaenoptera acutorostrata, from the Bay of Tabounsou, deposited at the CERESCOR Institute.

survey (NOAL WAN, Guinea, 29 September-21 October 2002). This observation, made from the RV 'Ala Awam', is supported by an identifiable photograph deposited at CNSHB and CEPEC.

\section{INCOMPLETELY DOCUMENTED AND REJECTED \\ RECORDS}

Sightings for an additional three cetacean species have been mentioned in unpublished reports, unfortunately with insufficient temporal and spatial details, thus impeding confirmation for Guinean waters. Nonetheless, we consider these records as likely valid, thanks to recognizable photographs (S.T. Diallo et al., 2002, 2004; Bamy et al., 2006). They include: shortfinned pilot whale Globicephala macrorhynchus Gray, 1846, rough-toothed dolphin Steno bredanensis (G. Cuvier in Lesson, 1828) and short-snouted common dolphin Delphinus delphis Linnaeus, 1758. Common dolphins Delphinus spp. have been reported from most coastal countries in Western Africa (e.g. Cadenat, 1959; Jefferson et al., 1997; Van Waerebeek, 1997; Van Waerebeek et al., 2000; Perrin \& Van Waerebeek, 2007; Weir, 2010). Cadenat (1959, table 1) lists a $D$. delphis record under 'confirmed' ('déterminations contrôlées') but did not provide supporting data.

Dutch ornithologist Jan Veen (in litteris, to K.V.W., 3 February 2010) sighted two S. teuszii in the 'area near Iles Tristao' during a seabird survey on 23 May 2009. No photographs are available, but J. Veen is familiar with the species from observations in Senegal's Saloum delta.

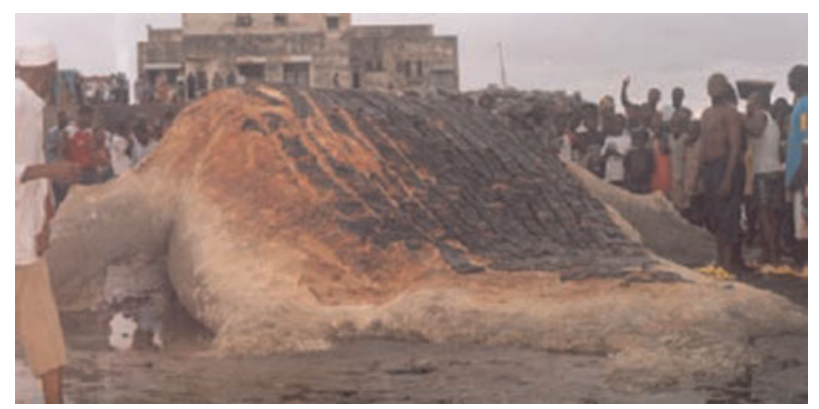

Fig. 8. The anterior body of a humpback whale, Megaptera novaeangliae, stranded in advanced decomposition at Téminitaye, near Conakry, on 26 September 2005. 


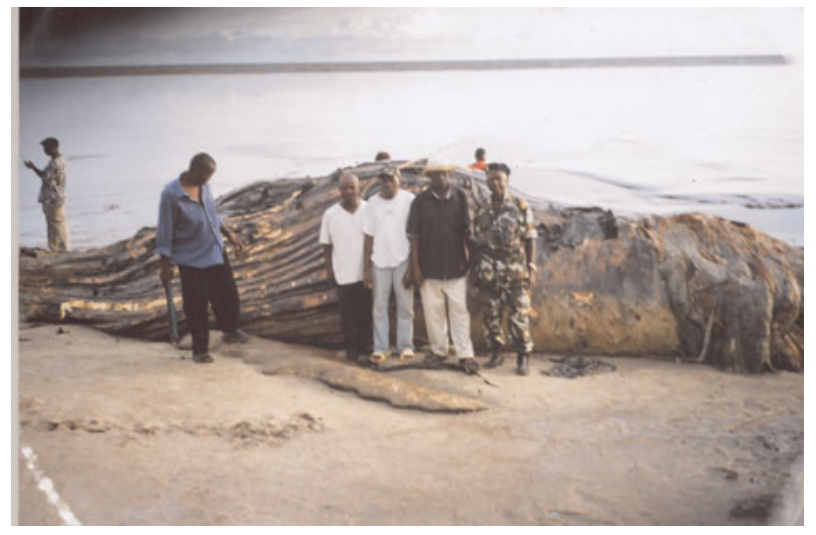

Fig. 9. Remains of an adult-sized humpback whale washed ashore at Taboriya, Boffa, on 22 July 2008.

Hammond \& Lockyer (1988) reported an offshore O. orca sighting (their record 81 ) off Guinea at $\sim 10^{\circ} \mathrm{N} 19^{\circ} \mathrm{W}$. Upon re-examination, Phil Hammond (in e-mail to K.V.W., 3 January 2007) indicated the record was erroneous. Hammond \& Lockyer (1988, p. 27) further state 'Cadenat (1959) reports observations in March off the coast of Guinea', however a careful reading of the O. orca paragraph (Cadenat, 1959, p. 1399) reveals records solely for Mauritania, Senegal and Côte d'Ivoire, but this inaccuracy has seeped into the literature (e.g. Jefferson et al., 1997, p. 90). In fact, no $O$. orca records are documented for the stretch of coast from southern Senegal (Casamance) to Liberia. In the broader eastern North Atlantic, O. orca is widespread, while nowhere common, in coastal and offshore areas (Hammond \& Lockyer, 1988). The question remains whether the species ventures into the shallow waters of Guinea-Bissau, Guinea and Sierra Leone.

Cadenat (1957, table p. 1366) listed Guinea as range state for the harbour porpoise 'Phocaena phocaena?' [sic] referring to an unsubstantiated sighting by the crew of a tuna boat operating at latitude $\sim 08^{\circ} 30^{\prime} \mathrm{N}$, in fact, off northern Sierra Leone. The species identification is considered equivocal as there are no other harbour porpoise Phocoena phocoena (Linnaeus, 1758) accounts from south of Senegal. Specifically the southernmost substantiated record is a by-catch recovered from fishermen at Ile de Fadiouth $\left(14^{\circ} 09^{\prime} \mathrm{N} 16^{\circ} 49^{\prime} \mathrm{W}\right)$ on Senegal's Petite Côte (Van Waerebeek et al., 2000). Waters further south and east, bathed by the Guinea Current, are almost certainly too warm for this temperate water species. The context ${ }^{2}$ strongly suggests that Cadenat (1957) himself did not lend much credibility to the Guinea report. Jefferson et al. (1997) also called it a questionable record.

On 13 November 2001, with logistical support from Guinean navy personnel, one of us (I.B.) collected cranial and some postcranial bones of a large unidentified balaenopterid stranded in October 2001 in the area of Kamsar $\left(10^{\circ} 39.1^{\prime} \mathrm{N} 14^{\circ} 37.0^{\circ} \mathrm{W}\right.$; 'whale' in Figure 1$)$, northern Guinea. Initially deposited at CNSHB, the skeleton was exported to France to an unknown destination. A single photograph of the partial skull suggests $M$. novaeangliae, but low resolution does not permit a definitive identification.

\footnotetext{
${ }^{2 ‘}$ Aucun d'eux n'a été capturé et les essais de détermination suivants ne sont appuyés sur l'examen d'aucune pièce particulière. . . a) bêtes de petite taille (du type Phocaena) ...' (Cadenat, 1957; p. 1368).
}

\section{DISCUSSIDN}

Five of the seven cetacean species (T. truncatus, K. breviceps, M. novaeangliae, B. acutorostrata and B. brydei) documented here represent first records for Guinea. This initial inventory is obviously incomplete in view of the modest survey effort and that known cetacean biodiversity in the western African region amounts to some 25-30 species (Perrin \& Van Waerebeek, 2007).

Population structure in S. teuszii is unclear including to what degree distributional continuity and gene flow exists between the provisionally defined 'South Guinea stock' and other defined stocks (Van Waerebeek et al., 2003, 2004). The species is listed on CITES Appendix I, is classified as 'Vulnerable' by IUCN and in 2008 was upgraded to the CMS Appendix 1 after WAFCET ${ }^{3}$ research raised concern about fisheries interactions, and wide distribution hiatuses were found between communities of low numbers (Van Waerebeek, 2003a; Van Waerebeek et al., 2003, 2004; Collins et al., 2004; Van Waerebeek \& Perrin, 2007; Weir, 2009, 2010). Like in Guinea-Bissau, Guinea's coast features prime S. teuszii habitat: warm and shallow waters $(0-40 \mathrm{~m}$ deep) on a shelf extending up to $200 \mathrm{~km}$ from shore (Chavance et al., 1998), extensive creeks with mangrove forest around four main river mouths, i.e. Río Komponi, Río Nuñez, Fatala, and Konkouré. The lack of sighting records of S. teuszii in Guinea may partly be blamed on the low level of near-shore survey effort. Nonetheless, because of both direct and circumstantial evidence of by-catches and since estimated numbers of the stocks for which some estimate was available have invariably been low, i.e. tens or hundreds of individuals (Collins et al., 2004; Van Waerebeek et al., 2004; Weir, 2009, 2010), concern is expressed about removals of any level. The Konkouré Estuary is protected since 1992 as a Ramsar wetlands site (No. 575) and is proposed as an ideal target area to initiate dedicated small-boat and shore-based surveys.

Tursiops truncatus in western Africa attains great body length, up to $368 \mathrm{~cm}$ in Senegal (Robineau \& Vely, 1997) and $330 \mathrm{~cm}$ in South Africa (Ross, 1984). Osteological characteristics have been discussed for dolphins from Mauritania, Senegal and Côte d'Ivoire (Cadenat \& Lassarat, 1959; Cadenat et al., 1959). The hypothesis of a Mauritania/ Senegal population linked to the north-west African upwelling zone and characterized by a long rostrum and a relatively smaller neurocranium (Robineau \& Vely, 1997) deserves further study. The Bonfi specimen suggests that such a form may have a considerably wider distribution off western Africa. So far no T. truncatus sightings are documented in Guinea, but as in neighbouring Guinea-Bissau where an inshore population inhabits much of the waters surrounding the Bijagos Archipelago (Spaans, 1990; Van Waerebeek et al., 2000, 2008), with very similar habitat it seems plausible that inshore T. truncatus also range over an appreciable part of Guinea's shallow coast. As inshore T. truncatus are a target of a live-capture fishery in Guinea-Bissau (Van Waerebeek et al., 2008) managers are reminded that offshore form T. truncatus may also occur, and in much larger groups, which could result in abundance over-estimates if populations are not clearly distinguished during surveys.

${ }^{3}$ CMS-sponsored, West African Cetacean Research and Conservation Projects (WAFCET). 
Little is known on the status of $S$. frontalis off western Africa, except that it is widely distributed in the region and validated records exist for the Canary Islands, Mauritania, Cape Verde, Senegal, Côte d'Ivoire, Ghana, Benin and Equatorial Guinea (Jefferson et al., 1997; Van Waerebeek et al., 2000; Perrin \& Van Waerebeek, 2007).

A few authors have studied the biology of $K$. breviceps in Atlantic Africa (Maigret \& Robineau, 1981; Robineau \& Vely, 1998) and it is documented only from temperate areas, i.e. north-west Africa and Namibia (Perrin \& Van Waerebeek, 2007). The large number of records suggests the species is fairly common off the Canary Islands (Casinos, 1977; Vonk \& Martin-Martel, 1988; De Stephanis \& Urquiola, 2006). Six dead animals recovered in 1999-2005 showed collision lesions, likely from strikes by fast ferries (De Stephanis \& Urquiola, 2006). There are fewer records elsewhere, one in Madeira (Maul \& Sergeant, 1977), two in Mauritania (Robineau \& Vely, 1998) and two strandings, four individuals in total, from Senegal (Cadenat, 1959; Maigret \& Robineau, 1981). No K. breviceps has been encountered in the Gulf of Guinea despite expanding field research (see e.g. Debrah, 2000; Ofori-Danson et al., 2003; Picanço et al., 2009; Van Waerebeek et al., 2009). The Dabondi specimen (see above) represents a $525 \mathrm{~km}$ southward extension of the species' known range in the north-eastern Atlantic, but it is unclear if this marks its approximate southern distribution boundary.

Balaenoptera brydei in the north-east Atlantic has not been the subject of dedicated research (see IWC, 1977; Kato, 2002). Two allopatric forms, an inshore and an offshore form, occur on the west coast of South Africa. The offshore form is thought to migrate north to the equator in winter (Best, 1977; Kato, 2002). However its relation to north-east Atlantic B. brydei is undocumented and in the meantime it is advisable to treat them as different stocks. Kanda et al. (2007), for instance, showed that gene flow between populations in the Pacific and Indian Oceans is low and that effective management actions should treat them as separate entities.

Similar uncertainties exist with respect to the population identity of B. acutorostrata off West Africa (Van Waerebeek et al., 1999; Perrin \& Brownell, 2002). The affinity of the Tabounsou specimen, which extended the documented range south from Senegal to Guinea, may lie with either the north-east Atlantic or central North Atlantic stocks (for definitions see Donovan, 1991) or it may be a member of a distinct, undescribed population. The boreal distribution range of the Antarctic minke whale Balaenoptera bonaerensis Burmeister, 1867 in the eastern Atlantic reaches at least into cool southern Angolan waters at $15^{\circ} 45^{\prime} \mathrm{S}$ (Best, 2007) but there is no indication that it inhabits tropical waters farther north, much less transgresses the equator into the northern hemisphere.

Increasing evidence shows that $M$. novaeangliae is not uncommon in tropical waters of the north-east Atlantic south-east of the Cape Verde Archipelago (CV). Slijper et al. (1964; chart 4) reported ten $M$. novaeangliae groups within a large area with perimeter $0^{\circ}-10^{\circ} \mathrm{N}$ and $10^{\circ}-20^{\circ} \mathrm{W}$, including Guinean waters, during February (1), March (1), April (2), September (5) and October (1), i.e. six or twice as many sightings during the southern hemisphere breeding season versus the three with northern hemisphere seasonality. The three records from Guinea documented here also show a southern hemisphere seasonality (July, September and October) in contrast with the spatially nearest stock, a northern hemisphere one, which breeds and overwinters in the CV from September until April (Lagendijk, 1984; Reiner et al., 1996; Wenzel et al., 2009). As CV whales annually arrive from the northern Atlantic at the earliest in September, it is highly implausible that some would by-pass the archipelago to arrive in Guinea, almost $1000 \mathrm{~km}$ to the south-east, in July. We hypothesize that the Guinean humpback whales documented here and the six southern hemisphere-consistent sightings from Slijper et al. (1964) indeed originate from the southern hemisphere. We suggest they comprise the northwestern range of the population known to breed/overwinter on the shelf of the Bight of Benin, northern Gulf of Guinea, from Nigeria to eastern Côte d'Ivoire, from August until early December (Van Waerebeek et al., 2001, 2007, 2009; Van Waerebeek, 2003b). We predict $M$. novaeangliae to seasonally occur also off Sierra Leone and Liberia. The northern Gulf of Guinea or Bight of Benin breeding population as discovered and named by Van Waerebeek et al. (2001, 2007, 2009) is, jointly with Gabon, Congo and Cabinda (Angola) referred to by the IWC as the B1 substock of Breeding Stock B in the south-east Atlantic Ocean (IWC, 2006). The three sightings with a northern hemisphere seasonality reported by Slijper et al. (1964) could belong to the CV population. The wide area offshore Guinea could harbour, out-of-phase, both northern hemisphere and southern hemisphere stocks, reminiscent of the hemispheric overlap off Pacific Costa Rica (Acevedo \& Smultea, 1995).

The mutilated M. novaeangliae carcass that washed ashore near Conakry was thought to have been struck by a ship, anteor post-mortem. Theoretically it could have been transported some distance on the bow bulb of a vessel, however, unlike other Balaenopteridae, only $4 \%$ of $M$. novaeangliae $(\mathrm{N}=$ 143) killed by vessels world-wide became, or remained, draped over ships' bows (Van Waerebeek \& Leaper, 2008), due perhaps to its anteriad more rotund shape and long flippers generating greater turbulence, causing the carcass to dislodge. Although rarely recognized, ship collisions with cetaceans occur far more frequently in African coastal waters than acknowledged and in some areas may constitute a major conservation problem (Félix \& Van Waerebeek, 2005; Van Waerebeek et al., 2007).

Over the past decades Guinean fisheries developed rapidly and in 1995 some 75,300 MT of fish products were landed, $69 \%$ artisanally with some 2300 canoes (Chavance et al., 1998; I. Diallo et al., 2004). In view of intense fishing effort and only a handful of documented by-catch cases, it is doubtful that these are representative for cetacean mortality levels. Lack of trained observers, limited port surveillance and few incentives to report illegal landings may be blamed. While there is no evidence for substantial dolphin landings, of the kind seen in Ghana for instance (Debrah, 2000; Ofori-Danson et al., 2003; Van Waerebeek et al., 2009), monitoring should intensify. Fin-fish, mollusc and other marine products may still largely satisfy local demand. Article 34 of Guinea's Fisheries Code (Code de la Pêche) clearly states that any capture of a marine mammal is prohibited ${ }^{4}$. However, as seen in other regions of the world (e.g. Mangel

\footnotetext{
${ }^{4}$ La chasse et la capture de toutes espèces de mammifères marins sont interdits en tous temps et en tous lieux'.
} 
et al., 2009), if a strong demand for cetacean products persists or develops, mere regulations do not offer sufficient deterrence. Guinea has ratified and is an active party to most international conventions relevant to cetacean conservation and management, primarily CMS, IWC and CITES, but also Ramsar, the United Nations Convention on the Law of the Sea (UNCLOS) and the CMS Memorandum of Understanding concerning the conservation of the manatee and small cetaceans of western Africa and Macaronesia.

In order to pool scarce resources, a national reference collection of aquatic mammal specimens and a national database is proposed in Conakry's Centre de Recherches Océanographiques de Rogbané (CERESCOR). It can provide ample office and laboratory space and it already curates a collection of marine biological specimens. Cetacean strandings offer good opportunities to collect valuable biological information and voucher specimens in an economic way. Unlike in Senegal, Mauritania and Cape Verde, no mass strandings are known for Guinea but events may have been overlooked.

\section{ACKNDWLEDGEMENTS}

We thank local fisheries agents for their valuable help with reporting and two anonymous referees for providing thoughtful comments on an earlier draft. The King Leopold III Fund for Nature Exploration and Conservation (Brussels) and the International Fund for Animal Welfare (IFAW) kindly granted support to K. Van Waerebeek for two missions to Guinea. Dr J. Van Goethem and Mr V. Papastavrou are thanked for recommending the applications. K. Van Waerebeek is very grateful also for the warm hospitality extended to him by the CNSHB Director and staff, as well as by the Bamy family in Conakry.

\section{REFERENCES}

Acevedo A. and Smultea M.A. (1995) First records of humpback whales including calves at Golfo Dulce and Isla del Coco, Costa Rica, suggesting geographical overlap of northern and southern hemisphere populations. Marine Mammal Science 11, 554-560.

Anonymus (1984) Compte-rendu sur les résultats de recherches halieutiques obtenus lors de la campagne du NS "Evrika" menée dans les eaux de la République de Guinée de 12 mai à 4 juillet 1984. Institut Atlantique de recherches scientifiques de l'Industrie des Pêches et l'Océanographie (AtlantNIRO). Unpublished Report, Kalinigrad.

Archer E. and Van Waerebeek K. (2000) Workshop in Guinea-Conakry on the conservation and management of marine mammals in West Africa. CMS Bulletin 11, 12-13.

Bamy I.L., Van Waerebeek K., Bah S.S., Dia M., Kaba B., Keita N., Konate S. and Tall H. (2006) The cetaceans of Guinea, a first check-list of documented species. IWC Scientific Committee document SC/58/ O15, 7pp (unpublished).

Best P.B. (1977) Two allopatric forms of Bryde's whale off South Africa. Reports of the International Whaling Commission Special issue 1 , $10-38$.

Best P.B. (2007) Whales and dolphins of the Southern African Subregion. Cape Town, South Africa: Cambridge University Press.

Cadenat J. (1956a) Un delphinidae encore mal connu de la côte occidentale d'Afrique: Sotalia teuszii Kükenthal 1892. Bulletin de l'Institut Français d'Afrique Noire 18A, 555-566.
Cadenat J. (1956b) A propos de cachalot. Notes Africaines 71, 82-92.

Cadenat J. (1957) Observations de Cétacés, Siréniens, Chéloniens et Sauriens en 1955-1956. Bulletin de l'IFAN 19A, 1358-1375.

Cadenat J. (1959) Rapport sur les petits Cétacés ouest-africains. Résultats des recherches entreprises sur ces animaux jusqu'au mois de mars 1959. Bulletin de l'Institut Français d'Afrique Noire 21A, 1367-1409.

Cadenat J., Doutre M. and Paraiso F. (1959) Notes sur les Delphinidés ouest-africains. Bulletin de l'Institut Français d'Afrique Noire $21 \mathrm{~A}$, $410-415$.

Cadenat J. and Lassarat A. (1959) Notes sur les Delphinidés ouest-africains IV. Sur un Prodelphinus indéterminé de Côte d'Ivoire. Bulletin de l'Institut Français d'Afrique Noire 21A, 777-781.

Casinos A. (1977) On a stranding of a pygmy sperm whale Kogia breviceps (Blainville, 1838) on the Canary Islands. Säugetierkundige Mitteilungen 25, 79-80.

Chavance P., Diallo A., Diallo M., Domain F., Drapeau L., Fautrel V., Guilavogui A., Morize E., Solie K. and Traore S. (1998) Atlas des Pêches Maritimes de Guinée 1997. Conakry: République de Guinée, Ministère de la Pêche et de l'Elevage, 25 pp.

CMS (2000) Rapport sur la Conservation et la gestion des petits cétacés de la Côte d'Afrique. Atelier, Conakry, Guinée, 8-12 May 20oo. Bonn, Germany: CMS/UNEP Secretariat.

Collins T., Ngouessono S. and Rosenbaum H.C. (2004) A note on recent surveys for Atlantic humpback dolphins, Sousa teuszii (Kükenthal, 1892) in the coastal waters of Gabon. IWC Scientific Committee document SC/56/SM23 (unpublished).

Cummings W.C. (1985) Bryde's whale Balaenoptera edeni Anderson, 1878. In Ridgway S.H. and Harrison R. (eds) Handbook of marine mammals, Volume 3. London: Academic Press, pp. 137-154.

De Stephanis R. and Urquiola E. (2006) Collisions between ships and cetaceans in Spain. IWC Scientific Committee document SC/58/BC 5 , 6 pp. (unpublished).

Debrah J.S. (2000) Taxonomy, exploitation and conservation of dolphins in the marine waters of Ghana. MPhil thesis. Department of Oceanography and Fisheries, University of Ghana, Legon. 86 pp.

Diallo I., Cissé I. and Bah A. (2004) Modèle trophique du système système côtier du plateau continental Guinéen. In Palomares M.L.D. and Pauly D. (eds) West African marine ecosystems: models and fisheries impacts. Fisheries Centre Research Reports 12. UBC, Vancouver: Fisheries Centre, pp. 113-123.

Diallo S.T., Bah F.B. and Sow M. (2007) La prise accidentelle d'un dauphin Tursiops truncatus (Montagu, 1821) au large de Conakry. Bulletin du Centre Halieutique de Boussoura 2, 65-66.

Diallo S.T., Yoshida H., Samoura A.B., Sow M., Camara M., Bah F.B., Monteiro V. Fall M., Da Fonseca L.M., Almeida A.F. and Rerambyath G.A. (2002) Campagne d'observation des cétacés dans les eaux côtières de l'Afrique du Nord Ouest (de la Guinée au Sénégal), 7-23 décembre 2002. Rapport de Mission, CNSHB, Ministère de la Pêche et de l'Aquaculture, République de Guinée. Unpublished internal report.

Diallo S.T., Bah F.B., Sow M., Camara Y., Cissé M., Monteiro V., Sylla S., Da Fonseca L.M., Almeida A.F.M., Rerambyath G.A., Yoshima I. and Yoshida H. (2004) Campagne d'observation des cétacés dans les eaux côtières de l'Afrique du Nord Ouest (de la Guinée au Sénégal), 23 janvier au 10 février 2004. Rapport de campagne, CNSHB, Ministère de la Pêche et de l'Aquaculture, République de Guinée. Unpublished internal report.

Domain F. and Bah M.O. (1993) Carte sédimentologie du plateau continental guinéen. Paris: ORSTOM, 15 pp. 
Donovan G.P. (1991) A review of the IWC stock boundaries. Reports of the International Whaling Commission Special issue 13, 39-68.

Félix F. and Van Waerebeek K. (2005) Whale mortality from ship strikes in Ecuador and West Africa. Latin American Journal of Aquatic Mammals 4, 55-6o.

Hammond P.S. and Lockyer C. (1988) Distribution of killer whales in the eastern North Atlantic. In Sigurjónsson J. and Leatherwood S. (eds) North Atlantic killer whales. Reykjavík, Iceland: Rit Fiskideildar XI. Hafrannsóknastofnunin, pp. 24-41.

Horwood J. (1990) Biology and exploitation of the minke whale. Boca Raton, FL: CRC Press.

IWC (1977) Report of the Special Meeting of the Scientific Committee on sei and Bryde's whales. Reports of the International Whaling Commission Special issue 1, 1-150.

IWC (2006) Annex H. Report of the sub-committee on the other Southern Hemisphere whale stocks. Journal of Cetacean Research and Management (Supplement) 8, 151-170.

Jefferson T.A., Curry B.A., Leatherwood S. and Powell J.A. (1997) Dolphins and porpoises of West Africa: a review of records (Cetacea: Delphinidae, Phocoenidae). Mammalia 61, 87-108.

Jonsgård A. (1951) Studies on the little piked whale or minke whale. Norsk Hvalfangst-Tidende 5, 209-231.

Junge G.C.A. (1950) On a specimen of the rare fin whale, Balaenoptera edeni, Anderson, stranded on Pulu Sugi near Singapore. Zoölogische Verhandelingen 9, 1-26.

Kaba B. and Boltachev A. (1986) Une baleine dans la Baie de Tabounsou. Horoya. Organe d'information de la République de Guinée. Vendredi 22 Août 1986, p.1 +5 .

Kanda N., Goto M., Kato H., McPhee M.V. and Pastene L.A. (2007) Population genetic structure of Bryde's whales (Balaenoptera brydei) at the inter-oceanic and trans-equatorial levels. Conservation Genetics 8, 853-864.

Kato H. (2002) Bryde's whales Balaenoptera edeni and B. brydei. In Perrin W.F., Würsig B. and Thewissen J.G.M. (eds) Encyclopedia of marine mammals. San Diego, CA: Academic Press, pp. 171-177.

Lagendijk P. (1984) Report of a study of the present status of humpback whales around the Cape Verdes Islands, March 1984. IWC Scientific Committee document SC/36/PS16, 8 pp.

Lönnberg E. (1931) The skeleton of Balaenoptera brydei Ö. Olsen. Arkiv för Zoologi 23A, 1-23, 8 plates.

Maigret J. (1994) Marine mammals and fisheries along the West African coast. Reports of the International Whaling Commission Special issue $15,307-316$.

Maigret J. and Robineau D. (1981) Le genre Kogia (Cetacea, Physeteridae) sur les côtes du Sénégal. Mammalia 45, 199-204.

Mangel J.C., Alfaro-Shigueto J., Van Waerebeek K., Cáceres C., Bearhop S., Witt M.J. and Godley B.J. (2009) Small cetacean captures in Peruvian artisanal fisheries: high despite protective legislation. Conservation Biology 143, 136-143.

Maul G.E. and Sergeant D.E. (1977) New cetacean records from Madeira. Bocagiana 43, $1-8$.

Mitchell E. and Kozicki V.M. (1975) Supplementary information on minke whale (Balaenoptera acutorostrata) from Newfoundland fishery. Journal of the Fisheries Research Board of Canada 32, 985-994.

Ofori-Danson P.K., Van Waerebeek K. and Debrah S. (2003) A survey for the conservation of dolphins in Ghanaian coastal waters. Journal of the Ghana Science Association 5, 45-54.
Olsen Ø. (1913) On the external characters and biology of Bryde's whale (Balaenoptera brydei), a new rorqual from the coast of South Africa. Proceedings of the Zoological Society of London 1913, 1073-1090.

Omura H., Kasuya T., Kato H. and Wada S. (1981) Osteological study of the Bryde's whale from the central South Pacific and eastern Indian Ocean. Scientific Reports of the Whales Research Institute 33, 1-26.

Perrin W.F. and Brownell R. Jr (2002) Minke whales B. acutorostrata and B. bonaerensis. In Perrin W.F., Würsig B. and Thewissen J.G.M. (eds) Encyclopedia of marine mammals. Amsterdam: Academic Press, pp. 91-136.

Perrin W.F. and Van Waerebeek K. (2007) The small-cetacean fauna of the west coast of Africa and Macaronesia: diversity and distribution. Western African Talks on Cetaceans and their Habitats, Symposium, Adeje, Tenerife, Islas Canarias, 16-20 October 2007.

Picanço C., Carvalho I. and Brito C. (2009) Occurrence and distribution of cetaceans in São Tomé and Príncipe tropical archipelago and their relation to environmental variables. Journal of the Marine Biological Association of the United Kingdom 89, 1071-1076.

Postel E. (1955) Les faciès bionomiques des côtes de Guinée française. Rapports et Procès-Verbaux des Réunions du Conseil International pour l'Exploration de la Mer 137, 10-13.

Reiner F., Dos Santos M.E. and Wenzel F. (1996) Cetaceans of the Cape Verde Archipelago. Marine Mammal Science 12, 434-443.

Robineau D. and Vely M. (1997) Données préliminaires (taille corporelle, craniométrie) sur le grand dauphin (Tursiops truncatus) des côtes d'Afrique du Nord-ouest (Mauritanie, Sénégal). Mammalia 61, $443-448$.

Robineau D. and Vely M. (1998) Les cétacés des côtes de Mauritanie (Afrique du Nord-Est). Particularités et variations spatio-temporelles de répartition: rôle des facteurs océanographiques. Revue d'Ecologie (Terre et Vie) 53, 123-152.

Ross G.J.B. (1984) The smaller cetaceans of the south east coast of southern Africa. Annals of the Cape Province Museum (Natural History) 15, 173-410.

Rougeron N. (1996) Etude de la répartition spatiale des ressources démersales du plateau continental guinéen. Relation avec le benthos et l'environnement physique. Mémoire de D.E.A, Ecole Nationale Supérieure Agronomique de Rennes, France, 27 pp. Unpublished thesis.

Sergeant D.E. (1963) Minke whale, Balaenoptera acutorostrata Lacépède, of the western North Atlantic. Journal of the Fisheries Research Board of Canada 20, 1489-1504.

Slijper E.J., Van Utrecht W.L. and Naaktgeboren C. (1964) Remarks on the distribution and migration of whales, based on observations from Netherlands ships. Bijdragen tot de Dierkunde 34, 1-105.

Soot-Ryen T. (1961) On a Bryde's whale stranded on Curaçao. Norsk Hvalfangst-Tidende 50, 323-332.

Spaans B. (1990) Dolphins in the coastal area of Guinea Bissau. Lutra 33, $126-133$.

Tormosov D.D., Budylenko G.A. and Sazhinov E.G. (1980) Biocenological aspects in the investigations of sea mammals. IWC Scientific Committee document SC/32/02, 9 pp.

Van Waerebeek K. (1997) Long-beaked and short-beaked common dolphins sympatric off central-west Africa. IWC Scientific Committee document $\mathrm{SC} / 49 / \mathrm{SM}_{46}, 5 \mathrm{pp}$.

Van Waerebeek K. (2003a) The Atlantic humpback dolphin: in retreat? CMS Bulletin 17, 10-11.

Van Waerebeek K. (2003b) A newly discovered stock of humpback whales in the northern Gulf of Guinea. CMS Bulletin 18, 6-7. 
Van Waerebeek K. and Leaper R. (2008) Second report of the IWC Vessel Strike Data Standardisation Working Group. IWC Scientific Committee document SC/6o/BC5.

Van Waerebeek K. and Perrin W.F. (2007) Conservation status of the Atlantic humpback dolphin, a compromised future? CMS Scientific Council Document CMS/ScC14/Doc.6, Bonn, Germany, 14-17 March 2007, 10 pp.

Van Waerebeek K., Ofori-Danson P.K. and Debrah J. (2009) The cetaceans of Ghana: a validated faunal checklist. West African Journal of Applied Ecology 15, 61-90.

Van Waerebeek K., André M., Sequeira M., Martin V., Robineau D., Collet A., Papastavrou V. and Ndiaye E. (1999) Spatial and temporal distribution of the minke whale Balaenoptera acutorostrata Lacépède 1804 in the southern Northeast Atlantic and the Mediterranean Sea, with comments on stock identity. Journal of Cetacean Research and Management 1, 223-237.

Van Waerebeek K., Ndiaye E., Djiba A., Diallo M., Murphy P., Jallow A., Camara A., Ndiaye P. and Tous P. (2000) A survey of the conservation status of cetaceans in Senegal, The Gambia and Guinea-Bissau. WAFCET-1 Report. CMS/UNEP Secretariat, Bonn, Germany, 80 pp.

Van Waerebeek K., Tchibozo S., Montcho J., Nobime G., Sohou Z., Sohouhoue P. and Dossou C. (2001) The Bight of Benin, a North Atlantic breeding ground of a Southern Hemisphere humpback whale population, likely related to Gabon and Angola substocks. IWC Scientific Committee document SC/53/IA21, 8 pp.

Van Waerebeek K., Barnett L., Camara A., Cham A., Diallo M., Djiba A., Jallow A.O., Ndiaye E., Samba Ould Bilal A. and Bamy I.L. (2003) Conservation of cetaceans and status of the Atlantic humpback dolphin in The Gambia and Senegal, 1999-2001. WAFCET-2 Report, UNEP/CMS, Bonn, Germany, 55 pp.

Van Waerebeek K., Barnett L., Camara A., Cham A., Diallo M., Djiba A., Jallow A.O., Ndiaye E., Samba Ould Bilal A.O. and Bamy I.L. (2004) Distribution, status and biology of the Atlantic humpback dolphin Sousa teuszii (Kükenthal, 1892). Aquatic Mammals 30, 56-83.

Van Waerebeek K., Baker A.N., Félix F., Gedamke J., Iñiguez M., Sanino G.P., Secchi E., Sutaria D., van Helden A. and Wang Y.
(2007) Vessel collisions with small cetaceans worldwide and with large whales in the Southern Hemisphere, an initial assessment. Latin American Journal of Aquatic Mammals 6, 43-69.

Van Waerebeek K., Bamy I.L., Jiddou A.M., Sequeira M., Diop M., Ofori-Danson P.K., Tchibozo S. and Campredon P. (2008) Indeterminate status of West African populations of inshore common bottlenose dolphins Tursiops truncatus cautions against opportunistic live-capture schemes. Technical Report, Fondation Internationale du Banc d'Arguin (FIBA; http://www.lafiba.org), 9 pp.

Vonk R. and Martin-Martel V. (1988) First list of odontocetes from the Canary Islands, 1980-1987. European Research on Cetaceans 2, 31-35.

Wada S., Oishi M. and Yamada T.K. (2003) A newly discovered species of living baleen whale. Nature 426, 278-281.

Weir C.R. (2009) Distribution, behaviour and photo-identification of Atlantic humpback dolphins Sousa teuszii off Flamingos, Angola. African Journal of Marine Science 31, 319-331.

Weir C.R. (2010) A review of cetacean occurrence in West African waters from the Gulf of Guinea to Angola. Mammal Review 40, 2-39.

Wenzel F.W., Allen J., Berrow S., Hazevoet C.J., Jann B., Seton R.E., Steiner L., Stevick P. López Suárez and Whooley P. (2009) Current knowledge on the distribution and relative abundance of humpback whales (Megaptera novaeangliae) off the Cape Verde Islands, Eastern North Atlantic. Aquatic Mammals 35, 502-510.

and

Yamada T.K., Kakuda T. and Tajima Y. (2008) Middle sized balaenopterid whale specimens in the Philippines and Indonesia. Memoirs of the National Museum of Natural Science Tokyo 45, 75-83.

\section{Correspondence should be addressed to:}

Koen Van Waerebeek

COREWAM-Ghana, PO Box PG99

EcoLab University of Ghana, and CEPEC

Museo de Delfines

Pucusana, Lima 20, Peru

email: corewam@gmail.com 